\title{
Analysis of SSR and AFLP Markers to Detect Genetic Diversity Among Selected Clones of Grapevine (Vitis vinifera L.) cv. Keshmeshi
}

\author{
H. Doulati Baneh*1, S.A. Mohammadi², H. Mahmoudzadeh ${ }^{1}$, F. de Mattia ${ }^{3}$ and M. Labra ${ }^{3}$ \\ (1) Department of Seed and Plant Breeding, Agricultural and Natural Resource Research Centre of West Azerbaijan, P.O. Box 365, \\ Uremia, Iran \\ (2) Department of Agronomy \& Plant Breeding, Faculty of Agriculture, University of Tabriz, Tabriz 51664, Iran \\ (3) Department of Biotechnology and Biosciences, University of Milano-Bicocca, Piazza della Scienza 2, I-20126 Milan, Italy
}

Submitted for publication: December 2008

Accepted for publication: February 2009

Key words: AFLP; clone; Keshmeshi; molecular markers; SSR; Vitis vinifera L.

\begin{abstract}
To assess the genetic differences between clones of grapevine (Vitis vinifera $\mathbf{L}$.) cv. Keshmeshi, ten selected clones from a clonal selection programme were analysed by 23 Simple Sequence Repeats (SSR) and seven AFLP primer combinations. No intra-varietal differences between the clones could be detected by SSRs, whereas eight out of the 499 AFLP fragments generated by the seven primer combinations were polymorphic. The number of markers ranged from 44 (E34-M34) to 97 (E31-M32), with an average of 71.3 fragments per primer combination. Cluster analysis based on the AFLP data separated all the clones of Keshmeshi in two groups. The first group included nine white berry skin clones without any genetic differences, and the second group with only a red berry skin clone. AFLP could only distinguish the red berry clone of Keshmeshi from other white berry clones.
\end{abstract}

Keshmeshi is one of the most important grapevine (Vitis vinifera L.) cultivars grown in Iran, and used mainly for table grape and raisin production (Doulati Baneh et al., 2007). Long-time cultivation and vegetative propagation of this cultivar have led to the production of many Keshmeshi individuals with many different characters originating from somatic mutation and viral diseases. In various regions of Iran, Keshmeshi has different names, e.g. Bidaneh, Sefid bidaneh and Sultani (Doulati Baneh et al., 2007). Developing a successful grape production programme requires the propagation of virus-free, true-to-type cultivars and clones (Silvestroni et al., 1997). Over time, virus diseases, epigenetic effects and DNA mutations cause differences among cultivar accessions that in some cases have led to superior clones being identified and subsequently propagated by growers (Sensi et al., 1996). Clonal selection has become the most important way to improve the quality of grape cultivars. As a consequence, there is a need for reliable and precise methods of clonal characterisation for use by breeders and nurseries (Moreno et al., 1998). Clone identification has traditionally been based on ampelography and ampelometry, but their expression can be affected by developmental and environmental factors and may cause several false attributions (Imazio et al., 2002), while DNAbased methods are not influenced by environmental factors and a large number of potential polymorphic sequences or markers are available. DNA tools such as SSRs and AFLPs are largely used for the characterisation and differentiation of grapevine clones or closely related accessions (Imazio et al., 2002; Popescu et al., 2002; Kozjak et al., 2003; Karataş et al., 2007), but on the basis of cultivars, markers and primer combination, contrasting results about the usefulness of molecular markers to assess genetic differences among clones have been reported (Sensi et al., 1996; Cervera et al., 1998; Scott et al., 2000; Vignani et al., 2002). In the present research, the possibility of differentiating Keshmeshi grapevine clones derived from a clonal selection programme by analysing SSR and AFLP markers was investigated.

\section{MATERIALS AND METHODS}

\section{Plant materials}

In this study, ten clones of Vitis vinifera cv. Keshmeshi were taken from a clonal selection vineyard in the agricultural research centre of West Azerbaijan, Uremia, Iran (Table 1). The agronomical traits related to raisin production (inflorescence and bunch size, bunch weight, berry weight, size and shape, time and uniformity of ripening, berry colour, TSS and yield) were recorded in three consecutive years (2005 to 2007). The evaluation was performed on twelve individuals of each clone. To exclude the possible effects of viruses on morphological characters, all clones were evaluated for their sanitary status. ELISA tests confirmed that all the selected clones were free of grapevine fanleaf virus (GFLV), grapevine leafroll virus (GLRV) and arabis mosaic virus (Armv).

\section{DNA extraction}

DNA extraction was performed using 1 to $2 \mathrm{~cm}$ long young leaves harvested from rooted cuttings based on the CTAB method described by Labra et al. (2001), excluding the purification steps.

\section{SSR analysis}

Twenty-three SSR loci (Table 2) were used for clonal identification (Thomas \& Scott, 1993; Bowers et al., 1999; Sefc et al., 1999). PCR was performed in a total volume of $10 \mu \mathrm{l}$ containing $20 \mathrm{ng}$ of DNA, $0.25 \mathrm{U}$ Taq DNA polymerase, $10 \mu \mathrm{M}$ of each primer, $200 \mu \mathrm{M}$ of each dNTP and reaction buffer $(50 \mathrm{mM} \mathrm{KCl}, 1.5 \mathrm{mM}$ $\mathrm{MgCl}_{2}, 10 \mathrm{nM}$ Tris-HCl, $\mathrm{pH} 9.0$ and $0.1 \%$ Triton $\left.\mathrm{X}-100\right)$. The PCR cycles consisted of an initial denaturation for $7 \mathrm{~min}$ at $94^{\circ} \mathrm{C}$, 35 cycles of denaturation $\left(45 \mathrm{~s}\right.$ at $\left.94^{\circ} \mathrm{C}\right)$, annealing $\left(30 \mathrm{~s}\right.$ at $\left.52^{\circ} \mathrm{C}\right)$ and extension $\left(1 \mathrm{~min}\right.$ at $\left.72^{\circ} \mathrm{C}\right)$, and a final extension at $72^{\circ} \mathrm{C}$ for 
7 min as described by Cresti (1997). The amplification products were separated by electrophoresis on $34 \mathrm{~cm}$ denaturing $6 \%$ polyacrylamide gel (run at $70 \mathrm{~W}, 60 \mathrm{~min}$ ) and then silver stained according to the protocol of the Promega (Madison, USA) kit.

\section{AFLP analysis}

AFLP analysis (Vos et al., 1995) was performed as described in European Patent 0534858 (Keygene, Wageningen, The Netherlands). Genomic DNA (200 ng) was digested for $3 \mathrm{~h}$ with a unit of each of the restriction enzymes EcoRI and MseI. The DNA fragments were ligated with T4 DNA ligase to an EcoRI adapter (5 pmol) and an $\mathrm{Mse}$ I adapter (50 pmol) in a final volume of $50 \mu \mathrm{l}$ at $37^{\circ} \mathrm{C}$ for $6 \mathrm{~h}$. The resulting mixture was used as the template in a pre-amplification reaction containing DNA primers (E01 and M01, Table 2) complementary to the cores of the EcoRI and MseI adapters respectively. The pre-amplification mixture $(50 \mu \mathrm{l})$ contained 20 $\mu \mathrm{l}$ digested/ligated DNA, $50 \mathrm{ng}$ of the selected primers, $200 \mu \mathrm{M}$ of each dNTP, 0.5 units Dynazyme II (Finnzymes, Keilaranta, Finland) and $5 \mu 1$ Dynazyme (Finnzymes, Keilaranta, Finland) 10x buffer. After 2 min at $94^{\circ} \mathrm{C}$, amplification was carried out for 20 cycles of denaturation $\left(45 \mathrm{~s}\right.$ at $\left.94^{\circ} \mathrm{C}\right)$, annealing $\left(30 \mathrm{~s}\right.$ at $\left.60^{\circ} \mathrm{C}\right)$ and extension (one min at $72^{\circ} \mathrm{C}$ ). After a final extension step ( 7 min at $\left.72^{\circ} \mathrm{C}\right)$, the pre-amplification products were diluted 1:50 (v/v) with water and used for selective amplification. This was carried out using one of the selective primers (E31, E32, E34 or E38; Table 2) complementary to the EcoRI adapter, and one of the primers (M31 M32 M34, M36, M38 or M39; Table 2) complementary to the MseI adapter. The EcoRI primer was end-labelled with $\gamma 33 \mathrm{P}-$ ATP (Amersham, Milan, Italy). The amplification mixture $(20 \mu \mathrm{l}$ final volume) contained $2.5 \mu \mathrm{l}$ of the diluted pre-amplification mixture, $5 \mathrm{ng}$ labelled EcoRI primer, $30 \mathrm{ng}$ MseI primer, $200 \mu \mathrm{M}$ of each dNTP, 0.5 units Dynazyme II (Finnzymes, Keilaranta, Finland) and $1 \mu$ l Dynazyme (Finnzymes, Keilaranta, Finland) buffer. After 2 min at $94^{\circ} \mathrm{C}$, amplification took place for 36 cycles under the following conditions: denaturation for $30 \mathrm{~s}$ at $94^{\circ} \mathrm{C}$; annealing for $30 \mathrm{~s}$ at $65^{\circ} \mathrm{C}$ for the first cycle, followed by lowering the temperature by $0.7^{\circ} \mathrm{C}$ for the next 12 cycles, then annealing at $56^{\circ} \mathrm{C}$ for the remaining 23 cycles, and extension for $60 \mathrm{~s}$ at $72^{\circ} \mathrm{C}$. A total of $1.5 \mu \mathrm{l}$ of the PCR-amplified mixture was added to an equal volume of loading buffer $(80 \%(\mathrm{v} / \mathrm{v})$ formamide, 1 mg ml-1 xylene cyanol FF, $1 \mathrm{mg} \mathrm{ml-1}$ bromophenol blue, $10 \mathrm{mM}$ EDTA, pH 8.0), denatured for 5 min at $92^{\circ} \mathrm{C}$, loaded on a $43 \mathrm{~cm}$ $5 \%(\mathrm{w} / \mathrm{v})$ denaturing polyacrylamide gel, and electrophoresed in TBE electrophoresis buffer for $3 \mathrm{~h}$ at $80 \mathrm{~W}$. The gel was fixed in $10 \%(\mathrm{v} / \mathrm{v})$ acetic acid and exposed to Kodak BioMax MR Film for $24 \mathrm{~h}$. Polymorphic bands were scored by visual inspection of the resulting autoradiograms. AFLP analysis was performed in duplicate.

\section{TABLE 1}

Denomination and different agronomical traits of ten Keshmeshi clones.

\begin{tabular}{|c|c|c|c|c|c|c|c|c|c|c|c|}
\hline Clone & Common name & $\begin{array}{c}\text { Inflorescence } \\
\text { number }\end{array}$ & $\begin{array}{c}\text { Bunch } \\
\text { number }\end{array}$ & $\begin{array}{c}\text { Bunch } \\
\text { length } \\
(\mathrm{cm})\end{array}$ & $\begin{array}{c}\text { Bunch } \\
\text { width } \\
\text { (cm) }\end{array}$ & $\begin{array}{c}\text { Berry } \\
\text { length } \\
(\mathrm{cm})\end{array}$ & $\begin{array}{c}\text { Berry } \\
\text { width } \\
(\mathrm{cm})\end{array}$ & TSS $^{1}$ & $\mathbf{T A}^{2}$ & $\begin{array}{c}\text { Mean } \\
\text { bunch/shoot }\end{array}$ & $\begin{array}{l}\text { Berry } \\
\text { color }\end{array}$ \\
\hline Kred & Keshmeshi Qermez & $92^{* *}$ & 86 & 26 & 15.3 & 1.4 & 1.3 & 22 & 1.2 & 1.8 & Red \\
\hline $\mathrm{K} 1$ & Keshmeshi Sefid & 85 & 80 & 29 & 12 & 1.3 & 1.2 & 20.5 & 0.98 & 1.8 & Yellow \\
\hline K3 & Keshmeshi Sefid & 96 & 96 & 29.5 & 11 & 1.5 & 1.4 & 21.5 & 0.96 & 2 & Yellow \\
\hline K4 & Keshmeshi Sefid & 90 & 81 & 29.5 & 12 & 1.7 & 1.4 & 21.5 & 0.81 & 1.6 & $\begin{array}{l}\text { Bright } \\
\text { yellow }\end{array}$ \\
\hline K9 & Keshmeshi Sefid & 100 & 90 & 25 & 14 & 1.5 & 1.3 & 22.5 & 0.97 & 1.7 & Yellow \\
\hline K12 & Keshmeshi Sefid & 80 & 70 & 28 & 12 & 1.4 & 1.2 & 24 & 0.76 & 1.9 & Yellow \\
\hline K25 & Keshmeshi Sefid & 127 & 121 & 25 & 13.4 & 1.3 & 1.1 & 21 & 1.05 & 1.7 & Yellow \\
\hline K35 & Keshmeshi Sefid & 80 & 70 & 28 & 14 & 1.4 & 1.2 & 23.2 & 0.95 & 1.8 & Yellow \\
\hline K59 & Keshmeshi Sefid & 136 & 115 & 25 & 14.3 & 1.3 & 1.1 & 21.4 & 1.01 & 1.9 & Yellow \\
\hline GRA1-1 & Keshmeshi Sefid & 80 & 73 & 26 & 13.5 & 1.7 & 1.3 & 22 & 0.95 & 1.85 & Yellow \\
\hline $\begin{array}{l}\text { Standard } \\
\text { error }\end{array}$ & & 0.36 & 0.15 & 0.12 & 0.13 & 0.16 & 0.02 & 0.02 & 0.1 & 0.2 & \\
\hline
\end{tabular}

** The average values for each parameter have been reported

${ }^{1}$ Total soluble solid

${ }^{2}$ Total acidity of fruit juice 
TABLE 2

Primer combinations used for AFLP analysis.

\begin{tabular}{ll}
\hline Name & DNA sequence \\
\hline M01 & 5'-GATGAGTCCTGAGTAA-3' \\
E01 & 5'-GACTGCGTACCAATTC-3' \\
E31 & 5'-GACTGCGTACCAATTCAAA-3' \\
E32 & 5'-GACTGCGTACCAATTCAAC-3' \\
E34 & 5'-GACTGCGTACCAATTCAAT-3' \\
E38 & 5'-GACTGCGTACCAATTCACT-3' \\
M31 & 5'-GATGAGTCCTGAGTAAAAA-3' \\
M32 & 5'-GATGAGTCCTGAGTAAAAC-3' \\
M34 & 5'-GATGAGTCCTGAGTAAAAT-3' \\
M36 & 5'-GATGAGTCCTGAGTAAACA-3' \\
M38 & 5'-GATGAGTCCTGAGTAAACT-3' \\
M39 & 5'-GATGAGTCCTGAGTAAAGA-3' \\
\hline
\end{tabular}

\section{Statistical analysis}

Allele sizes of the SSR bands were determined by internal size markers and by comparison with a standard set of microsatellite reference alleles (This et al., 2004). As far as AFLP is concerned, the amplified bands were scored as absent (0) or present (1) and the resulting data matrix was analysed using the GENSTAT V statistical program (Payne et al., 1993). Diversity levels were estimated on the basis of the percentage of polymorphic bands out of the total bands scored. Similarity-dissimilarity matrices were computed using the Jaccard coefficient. Dendrograms were constructed on the basis of UPGMA (unweighted pair-group method with arithmetical averages).

\section{RESULTS AND DISCUSSION}

\section{SSRs}

Ten clones of Keshmeshi grapevines with different quality and quantity traits (Table 1) were analysed at 23 SSR loci. Table 3 shows the allele size obtained for Keshmeshi at the analysed SSR loci. No polymorphism was found among the clones of the Keshmeshi cultivar and this technique could not differentiate the clones. These data suggest that the morphological and agronomical differences observed among these clones could not readily be explained on the basis of SSR regions. The same conclusion was reported by Silvestroni et al. (1997), who analysed Sangiovese and Fortana clones, and by Imazio et al. (2002), who applied SSR analysis to distinguish Traminer clones. However, some success in differentiating clones by SSR has been reported (Regner et al., 2000; Kozjak et al., 2003). In our research, clonal selection within the Keshmeshi cultivar was done on the basis of differences in quantitative traits, e.g. soluble solids, yield, berry weight and some qualitative traits, e.g. colour of the berry. These differences may result from slight changes in DNA sequences in the coding regions or epigenetic effects that are not detectable with SSR analysis.

\section{TABLE 3}

Allele length at 23 SSR loci developed from 10 clones of Keshmeshi.

\begin{tabular}{cccccc}
\hline Locus & Alleles & Locus & Alleles & Locus & Alleles \\
\hline VVMD5 & $234: 234$ & D12 & $158: 184$ & VVS3 & $212: 218$ \\
VVMD7 & $240: 254$ & UCH29 & $211: 300$ & VVS4 & $174: 174$ \\
VVMD8 & $145: 152$ & ISV2 & $143: 143$ & VrZAG47 & $159: 169$ \\
VVMD17 & $222: 222$ & ISV3 & $133: 139$ & VrZAG62 & $188: 188$ \\
VVMD21 & $249: 258$ & ISV4 & $197: 197$ & VrZAG64 & $143: 159$ \\
VVMD25 & $243: 253$ & G7 & $106: 118$ & VrZAG79 & $248: 260$ \\
VVMD26 & $247: 249$ & G10 & $149: 149$ & VrZAG83 & $194: 194$ \\
VVMD27 & $181: 190$ & VVS2 & $145: 151$ & & \\
\hline
\end{tabular}

TABLE 4

AFLP primer combinations, total bands detected and number of polymorphic bands.

\begin{tabular}{ccc}
\hline Primer combination & Total bands & Polymorphic bands \\
\hline E32-M38 & 48 & 1 \\
E34-M34 & 44 & 0 \\
E38-M36 & 85 & 1 \\
E34-M38 & 62 & 0 \\
E31-M32 & 97 & 2 \\
E32-M31 & 96 & 4 \\
E34-M39 & 67 & 0 \\
\hline
\end{tabular}

\section{AFLPs}

Seven AFLP primer combinations generated 499 scorable fragments ranging from 44 (E34-M34) to 97 (E31-M32), with an average of 71.3 fragments per primer combination (Table 4). Eight out of the 499 AFLP fragments were polymorphic. Starting from this, cluster analysis (Figure 1) based on polymorphic AFLP markers separated the clones into two groups: 1) nine clones of Keshmeshi Sefid (yellow-skinned berries) without any polymorphism and 2) a Keshmeshi Qermez clone (red-skinned berries). The genetic similarity between the two groups was about 98.5 , confirming their clonal origin.

The main difference between the Keshmeshi Qermez (Kred) and Keshmeshi Sefid clones is the colour of the berry skin, i.e. Keshmeshi Qermez is a red-skinned berry while Keshmeshi Sefid is a white-yellow berry. The berry colour is determined by the accumulation of anthocyanins, and a mutation appears to be responsible for the difference in berry colour. Recent research (Kobayashi et al., 2004; Hirochika et al., 2006) showed that $M y b$-related genes such as VvmybA1 regulate anthocyanin biosynthesis, and a retrotransposon-induced mutation in these genes is associated with the loss or synthesis of pigments in cultivars of Vitis vinifera L. Bud mutation from white-skinned Italia cultivars to red-skinned Ruby Okuyama caused by the deletion of a retrotransposon inserted in VvmybAl has been reported 


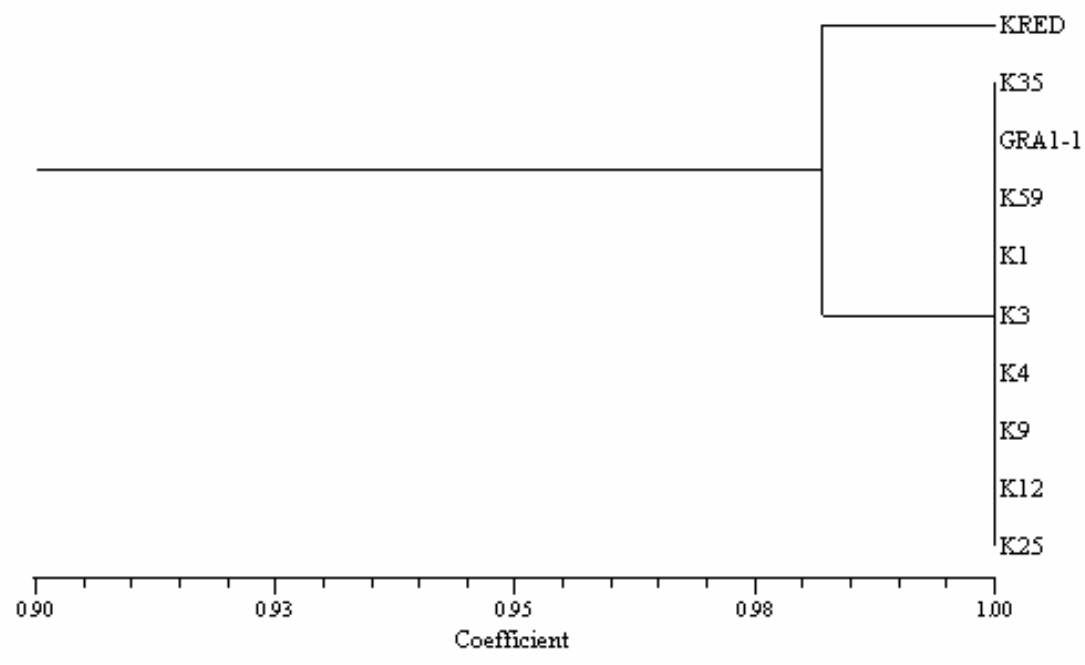

FIGURE 1

Dendrogram of genetic relationships among nine Keshmeshi Sefid clones and Keshmeshi Qermez (Kred) based on AFLP data.

(Kobayashi et al., 2005). Therefore, it could be hypothesised that a spontaneous retrotransposon-induced mutation in the $M y b$ genes in a bud of the Keshmeshi Sefid cultivar caused the re-synthesis of pigments and, subsequently, Keshmeshi Qermez was derived. To clarify this difference between the two clones, the analysis should be extended by using retrotransposon markers.

Our results show that the nine Keshmeshi clones (group 1) are genetically uniform and that the differences (cluster, bunch and berry number, length, width, etc.) that exist among them are not readily explainable on the basis of AFLP analysis. This phenotypic variation could be explained by a differential expression of certain structural genes regulated by epigenetic changes, or by the occurrence of mutations. The existence of a correlation between changes in the methylation state of particular gene sequences and the expression of a mutant phenotype has been shown clearly by Imazio et al. (2002). Moreover, the mutation might be restricted to a very small region of the genome, or might involve a point mutation in a coding region that might be difficult to detect by AFLP markers. To explore a larger portion of the genome, more primers could be assayed (Fanizza et al., 2003).

Based on different number and primer combinations and different cultivars, there are contrasting results regarding the capability of AFLP to assess genetic differences among clones. Some authors (Cervera et al., 1998) failed to detect polymorphisms among clones, while others (Sensi et al., 1996; Scott et al., 2000) could differentiate clones by means of AFLP markers.

The sequencing of the grapevine genome was recently completed (Jaillon et al., 2007) and this opens the real possibility to improve DNA technology to analyse specific genes related to different morphological and agronomical traits. These new technologies will be useful in clarifying the genetic bases of clonal differences, and in excluding any homonymous or wrong attributions based only on observations of morphological characters.

\section{LITERATURE CITED}

Bowers, J.E., Dangl, G.S. \& Meredith, C.P., 1999. Development and characterization of additional microsatellite DNA markers for grape. Am. J. Enol. Vitic. 50, 243-246.

Cervera, M.T., Cabezas, J.A., Sancha, J.C., Martinez, F. \& Martinez, J.M., 1998. Application of AFLP to the characterization of grapevine Vitis vinifera genetic resources. A case study with accessions from Rioja (Spain). Theor. Appl. Genet. 97, 51-59.

Cresti, M., 1997. Detection of genetic diversity among clones of cv. Fortana (Vitis vinifera L.) by microsatellite DNA polymorphism analysis. Vitis 36, 147-150.

Doulati Baneh, H., Mohammadi, S.A., Labra, M., Nazemieh, A., De Mattia, F. \& Mardi, M., 2007. Chloroplast microsatellite markers to assess genetic diversity in wild and cultivated grapevines of Iran. Pakistan J. Biol. Sci. 10, 1855-1859.

Doulati Baneh, H., Grassi, F., Mohammadi, S.A., Nazemieh, A., De Mattia, F., Imazio, S. \& Labra, M., 2007. The use of AFLP and morphological markers to study Iranian grapevine germplasm to avoid genetic erosion. J. Hort. Sci. Biotechnol. 82, 745-752.

Fanizza, G., Chaabane, R., Ricciardi, L. \& Resta, P., 2003. Analysis of a spontaneous mutant and selected clones of cv. Italia (Vitis vinifera) by AFLP markers. Vitis 42, 27-30.

Hirochika, H., Kobayashi, S., Goto-Yamamoto, N., Jeong, S.T., Sueta, T., Mitani, N. \& Azuma, A., 2006. A skin color mutation of grapevine, from black-skinned Pinot Noir to white-skinned Pinot Blanc, is caused by deletion of the functional VvmybA1 allele. Biosci. Biotechnol. Biochem. 70, 1506-1508.

Imazio, S., Labra, M., Grassi, F., Winfield, M., Bardini, M. \& Scienza, A., 2002. Molecular tools for clone identification: the case of the grapevine cultivar Traminer. Plant Breeding 121, 531-535.

Jaillon, O., Aury, J.M., Noel B., Policriti, A., Clepet, C., 2007. The grapevine genome sequence suggests ancestral hexaploidization in major angiosperm phyla. Nature 449, 463-467.

Karataş, H., Değirmenci, D., Velasco, R., Vezzulli, S., Bodurand, C. \& Sabit Ağaoğlu, Y., 2007. Microsatellite fingerprinting of homonymous grapevine (Vitis vinifera L.) varieties in neighboring regions of South-East Turkey. Scientia Horticulturae 114, 164-169.

Kobayashi, S., Goto-Yamamoto, N. \& Hirochika, H., 2004. Retrotransposoninduced mutations in grape skin color. Science 304, 982. 
Kobayashi, S., Goto-Yamamoto, N. \& Hirochika, H., 2005. Association of VvmybA1 gene expression with anthocyanin production in grape (Vitis vinifera) skin-color mutants. J. Jpn. Soc. Hort. Sci. 74, 196-203.

Kozjak, P., Korosec-Koruza, Z. \& Javornik, B., 2003. Characteristics of cv. Refosk (Vitis vinifera L.) by SSR markers. Vitis 42, 83-86.

Labra, M., Carreno-Sanchez, E., Bardini, M., Basso, B., Sala, F. \& Scienza, A., 2001. Extraction and purification of DNA from grapevine leaves. Vitis 40, 101-102.

Moreno, S., Martin, J.P. \& Ortiz, J.M., 1998. Inter-simple sequence repeats PCR for characterization of closely related grapevine germplasm. Euphytica 101,117-125.

Payne, R.W., Lane, P.W., Ainsley, A.E., Bricknell, K.E., Digby, P.C.N., Harding, S.A., Leech, P.K., Simpson, H.R., Todd, A.D., Verrier, P.J., White, R.P., Gower, J.C. \& Tuncliffe, W.G., 1993. Genstat 5 Release 3 Reference Manual. Clarendon Press, Oxford.

Popescu, C.F., Flak, A. \& Glimelius, K., 2002. Application of AFLPs to characterize somaclonal variation in anther-derived grapevines. Vitis 41, 177-182.

Regner, F., Wiedeck, E. \& Stadlbaur, A., 2000. Differentiation and identification of White Riesling clones by genetic markers. Vitis 39, 103-107.

Scott, K.D., Ablett, E.M., Lee, L.S. \& Henry, R.J., 2000. AFLP markers distinguishing an early mutant of Flame seedless grape. Euphytica 113, 243-247.

Sefc, K.M., Regner, F., Turetschek, E., Glössl, J. \& Teinkellner H., 1999 Identification of microsatellite sequences in Vitis riparia and their applicability for genotyping of different. Vitis species. Genome 42, 1-7.
Sensi, E., Vignani, R., Rohde, W. \& Biricolti, S., 1996. Characterization of genetic biodiversity with $V$. vinifera L. Sangiovese and Colorino genotypes by AFLP and ISTR DNA marker technology. Vitis 35, 183-188.

Silvestroni, O., Di Pietro, D., Intrieri C., Vignani, R., Filippetti I., Del Casino, C., Scali, M. \& Cresti, M., 1997. Detection of genetic diversity among clones of cultivar Fortana (Vitis vinifera L.) by microsatellite DNA polymorphism analysis. Vitis $35,147-150$.

This, P., Jung, A., Boccacci, P., Borrego, J., Botta, R., Costantini, L., Crespan, M., Dangl, G.S., Eisenheld, C., Ferreira-Monterio, F., Grando, S., Ibanez, J., Lacombe, T., Laucou, V., Magalhaes, R., Meredith, C.P., Milani, N., Peterlunger, E., Regner, F., Zulini, L. \& Maul, E., 2004. Development of a standard set of microsatellite reference alleles for identification of grape cultivars. Theor. Appl. Genet. 109, 1448-1458.

Thomas, M.R. \& Scott, N.S., 1993. Microsatellite repeats in grapevine reveal DNA polymorphisms when analysed as sequence-tagged sites (STSs). Theor. Appl. Genet. 86, 985-990.

Vignani, R., Scali M., Masi, E. \& Cresti, M., 2002. Generic variability in Vitis vinifera L. "Sangiovese" assessed by microsatellite and non-radioactive AFLP test. Electronic J. Biotec. 5, 20-124.

Vos, P., Hogers, R., Bleeker, M., Reijans, M., Van de Lee, T., Hornes, M., Frijters, A., Pot, J., Peleman, J., Kuiper, M. \& Zabeau, M., 1995. AFLP: a new technique for DNA fingerprinting. Nucl. Acids Res. 23, 4407-4414 